\title{
In vitro adenosine deaminase inhibitory activity of some selected plant extracts and chemical compounds
}

\author{
Aris Tercan' ${ }^{1}$, Özlem Saçan ${ }^{1}$ (D) \\ 'Istanbul University-Cerrahpasa, Faculty of Engineering, Department of Chemistry, Avcilar, Istanbul, Turkey
}

ORCID IDs of the authors: A.T. 0000-0003-4805-5337; Ö.S. 0000-0001-6503-4613

Cite this article as: Tercan, A., \& Sacan, O. (2020). In vitro adenosine deaminase inhibitory activity of some selected plant extracts and chemical compounds. Istanbul Journal of Pharmacy, 50 (3), 283-288.

\begin{abstract}
Background and Aims: Adenosine deaminase (EC 3.5.4.4, ADA) is distributed in all human tissues. It catalyses the deamination of adenosine (deoxyadenosine) to inosine (deoxyinosine) via removal of an amino group. The determination of ADAinhibition is of extreme significance in the field of fundamental research and clinical diagnosis. In our study, the effects of various plant extracts and chemicals on ADA activity were investigated.

Methods: Adenosine deaminase activity was determined spectrophotometrically at $625 \mathrm{~nm}$.

Results: The inhibitory activities of the extracts and chemical compounds increased in a dose-dependent manner. Among the plant extracts used, lemon extract was observed to exhibit the highest ADA inhibition activity with an IC $\mathrm{C}_{50}$ value of $0.05 \pm 0.001$ $\mathrm{mg} / \mathrm{mL}$, while quercetin had the highest ADA inhibition ( $\left(\mathrm{C}_{50}\right.$ value of $0.004 \pm 0.0005 \mathrm{mg} / \mathrm{mL}$ ) among the chemical compounds. All plant extracts and chemical compounds showed ADA inhibition activities.

Conclusion: The obtained results indicate that plant extracts and some chemical compounds examined in this study can be a potential source of novel ADA-inhibitors for therapeutics.
\end{abstract}

Keywords: Adenosine deaminase, enzyme inhibition, plant extracts, chemical compounds

\section{INTRODUCTION}

Cancer is a complicated disease that varies from one patient to another in terms of manifestation, development and outcomes. It is a multi-step process whereby cells undergo metabolic and behavioural changes leading to extreme and timeless proliferation, which escapes from the observation of the immune system, and which consequently leads to the invasion of distant tissues to form metastases (Markman \& Shiao, 2015). Due to the increasing frequency of cancer and cancer related deaths, in addition to complications in cancer treatment, the presence of cancer-causing factors, and the need for social and psychological support, cancer is regarded as a major public health problem worldwide and its significance is increasing day by day.

The most important factors in the development of cancer include the use of tobacco and tobacco products, alcohol consumption, malnutrition, obesity, viruses, exposure to ionizing radiation, occupational diseases and environmental pollution (Soerjomataram et al., 2018). Different treatment modalities such as chemotherapy, radiotherapy, surgical methods, hormone therapy and biological methods have been the main methods of cancer treatment. (Zaigham \& Sakina, 2018). Adenosine deaminase (EC 3.5.4.4, ADA), is distributed in all human tissues. It is a vital enzyme in intracellular and extracellular purine metabolism, and

Address for Correspondence:

Özlem SAÇAN, e-mail: osacan@istanbul.edu.tr

This work is licensed under a Creative Commons Attribution 4.0 International License. 
its primary function is the deamination of deoxyadenosine into deoxyinosine by removing an amino group (Dolezelova, Zurovec, Dolezal, Simek, \& Bryant, 2005). It also plays an essential role in the maturation, function and maintenance of immunology response (Van der Weyden \& Kelley, 1976; Fleischman et al., 1998). Accumulating evidences have proven that ADA deregulation or altered expression is closely related to many malignant diseases. For example, about $20 \%$ of severe combined immunodeficiency disease (SCID) cases are linked to ADA deficiency (Aiuti et al., 2009; Aldrich, Blackburn, \& Kellems, 2000). By contrast, over-expression of ADA is a great potential cause of liver cancer, acute leukaemia, oesophagus tumors and so on (Hoffbrand \& Janossy, 1981; Ibiş et al., 2007). Moreover, increased serum ADA activity is reported in laryngeal cancer (Canbolat, Akyol, Kavutcu, Isik, \& Durak, 1994), head and neck cancer (Lal, Munjal, Wig, \& Saini, 1987), breast cancer (Walia, Mahajan, \& Singh, 1995) and lung cancer (Nishihara, Akedo, Okada, \& Hattori, 1970). Plants have been used for therapeutic purposes for centuries. Their extracts exhibit protective effects due to abundance of secondary metabolites, therefore are potential sources of novel compounds for treatment of various diseases. As a consequence, the determination of ADA-inhibition potentials of plant extract is of extreme significance in fundamental research and clinical cancer therapy (Wang, Chen, Su, Wang, \& Su, 2019).

In this study, we investigated adenosine deaminase activity of some selected plant extracts and chemical compounds.

\section{MATERIALS AND METHODS}

\section{Preparation of aqueous extracts}

Plants were collected from local markets in Istanbul. The plant materials were washed with distilled water and dried at room temperature. In the study, aqueous extracts of edible parts of plants were prepared. Dried plants $(5 \mathrm{~g})$ were extracted by adding distilled water and then they were boiled for 7 hours. The extracts were filtered and the filtrates were evaporated under reduced pressure using a rotary evaporator. These extracts were used in the experiment.

\section{Preparation of ADA homogenate}

Mature male bovine liver was used as the source of ADA in the study. The collected liver was homogenized in phosphate buffer ( $\mathrm{pH}=8.8$ ) to make up a 10\% (w/v) homogenate. The homogenate was employed in the ADA inhibitory assay.

\section{Adenosine deaminase inhibitory activity assay}

Adenosine deaminase inhibition was performed according to the method of Blum and Schwedt (Blum \& Schwedt, 1998). 1 $\mathrm{mL}$ of acetate buffer ( $\mathrm{pH}=5.6$ ) was added to each tube. Then $0.5 \mathrm{~mL}$ of inhibitor's solutions was added to the respective tube, followed by $0.1 \mathrm{~mL}$ of homogenate, and incubation at $25^{\circ} \mathrm{C}$ for $60 \mathrm{~min}$. A $0.1 \mathrm{~mL}$ of adenosine as substrate was thereafter added to each tube, incubated for $30 \mathrm{~min}$ at $25^{\circ} \mathrm{C}$, before addition of $1 \mathrm{~mL}$ of $1 \mathrm{M}$ sodium hydroxide solution, $1 \mathrm{~mL}$ of phenol solution and $50 \mu \mathrm{L}$ of hypochloric acid ( $\mathrm{HOCl}$ ). After incubation for 45 minutes at room temperature, absorbance was taken spectrophotometrically at $625 \mathrm{~nm}$. In the control solution, distilled water was added in place of the inhibitor. Erythro-
9-(2-Hydroxy-3-nonyl)adenine hydrochloride EHNA was used as a standard compound. The inhibition ADA was calculated according to the following formula

Inhibition $(\%)=\left[\frac{A_{c}-A_{n}}{A_{c}}\right] \times 100$

Where: $A_{c}=$ Absorbance of control and $A_{n}=$ Absorbance of test.

For ADA inhibitor activities, the results are given as half maximal inhibitory concentrations ( $\left(\mathrm{C}_{50}\right.$ values) calculated regression prepared from the concentrations of samples.

\section{RESULTS}

The ADA inhibitor activities of plant extracts and chemical compounds were found to increase in a dose dependent manner. A higher ADA inhibitor activity is associated with a lower $I C_{50}$ value. The $I C_{50}$ values of plant extracts and chemical compounds used in the ADA inhibition studies are presented in Table 1 and 2 respectively. For ADA, plant extract showed $I_{50}$ values between $0.05 \pm 0.001 \mathrm{mg} / \mathrm{mL} 0.05 \pm 0.001 \mathrm{mg} / \mathrm{mL}$ and $22.02 \pm 0.40 \mathrm{mg} / \mathrm{mL}$.

Among the plant extracts, lemon had the highest ADA inhibition activity resulting from its lowest $I C_{50}$ value of $0.05 \pm 0.001$ $\mathrm{mg} / \mathrm{mL}$, followed by black grape $(3.55 \pm 0.03 \mathrm{mg} / \mathrm{mL})$, pomegranate $(4.43 \pm 0.55 \mathrm{mg} / \mathrm{mL})$, kiwi $(5.11 \pm 0.02 \mathrm{mg} / \mathrm{mL})$ and quince $(6.37 \pm 0.17 \mathrm{mg} / \mathrm{mL})$ respectively. The lowest ADA inhibition was observed in extract of grapefruit and red apple with an $I_{50}$ of $22.02 \pm 0.40 \mathrm{mg} / \mathrm{mL}$ and $16.84 \pm 0.57 \mathrm{mg} / \mathrm{mL}$ respectively.

Among the chemical compounds used, quercetin exhibited the highest ADA inhibitor effect, with the lowest $I C_{50}$ value of $0.004 \pm 0.0005 \mathrm{mg} / \mathrm{mL}$. This is followed by kaempferol, myrisitine and xanthine with $\mathrm{IC}_{50}$ values of $0.06 \pm 0.003 \mathrm{mg} /$ $\mathrm{mL}, 0.081 \pm 0.002 \mathrm{mg} / \mathrm{mL}$ and $0.14 \pm 0.005 \mathrm{mg} / \mathrm{mL}$ respectively. EHNA which was employed as the standard inhibitor had an $I_{50}$ value of $6.38 \pm 1.13 \mathrm{mg} / \mathrm{mL}$. Adenosine deaminase inhibitor activities of chemical compounds and standard compounds decreased in following order: Quercetin> kaempferol $>$ myristicin $>$ xanthine $>$ guanine $>$ adenine $>$ $\mathrm{AgNO}_{3}>\mathrm{CuSO}_{4} .7 \mathrm{H}_{2} \mathrm{O}>\mathrm{EHNA}>$ biotin $>$ vitamin $\mathrm{U}>$ guanosine $>$ cytosine $>$ uracil $>$ allopurinol $>$ nicotinamide $>\mathrm{VOSO}_{4}$ $\mathrm{H}_{2} \mathrm{O}>\mathrm{ZnSO}_{4} \cdot 7 \mathrm{H}_{2} \mathrm{O}$.

\section{DISCUSSION}

Inadequate physical activity, obesity, unbalanced nutrition, and alcohol and tobacco consumption are among the most common risk factors for cancer. These factors are considered to cause more than half of all cancers (Colditz \& Wei, 2012). In addition, environment factors such as UV radiation, smoke and radon exposure increase the risk of cancer development. Some dietary foods may be protective, while others may increase the risk of cancer (Ozdemir, Serin, \& Savas, 2018). Reports have shown that $70 \%$ of all cancers are linked or associated with nutritional habits, and an estimated $40 \%$ of cancer-related deaths (Willett, 2000). The leading methods in cancer treatment are chemotherapy, 
Table 1. Adenosine deaminase inhibitory activity of some selected aqueous plant extracts.

\begin{tabular}{|c|c|c|c|c|}
\hline Plant extract & $\begin{array}{l}\text { Collected of } \\
\text { plants }\end{array}$ & $\begin{array}{l}\text { Concentration } \\
(\mathrm{mg} / \mathrm{mL})\end{array}$ & Inhibition (\%)* & $\mathrm{IC}_{50}(\mathrm{mg} / \mathrm{mL})$ * \\
\hline Black grape & Fruit & $\begin{array}{c}1 \\
1.5 \\
2 \\
2.5\end{array}$ & $\begin{array}{l}11.47 \pm 0.93 \\
21.64 \pm 2.32 \\
28.17 \pm 0.70 \\
33.58 \pm 0.09\end{array}$ & $3.55 \pm 0.03$ \\
\hline Black radish & Root & $\begin{array}{c}5 \\
10 \\
15 \\
20\end{array}$ & $\begin{array}{l}26.77 \pm 2.11 \\
43.94 \pm 1.62 \\
70.72 \pm 0.38 \\
88.63 \pm 0.75\end{array}$ & $10.73 \pm 0.32$ \\
\hline Cabbage & Vegetables & $\begin{array}{c}10 \\
12.5 \\
15 \\
20\end{array}$ & $\begin{array}{l}51.78 \pm 2.74 \\
56.49 \pm 3.42 \\
65.81 \pm 1.01 \\
79.56 \pm 1.55\end{array}$ & $9.48 \pm 1.10$ \\
\hline Grapefruit & Fruit & $\begin{array}{l}10 \\
15 \\
20 \\
25\end{array}$ & $\begin{array}{l}16.84 \pm 0.66 \\
25.22 \pm 0.80 \\
42.89 \pm 4.81 \\
60.87 \pm 1.41\end{array}$ & $22.02 \pm 0.40$ \\
\hline Green apple & Fruit & $\begin{array}{c}5 \\
10 \\
15 \\
20\end{array}$ & $\begin{array}{l}19.59 \pm 0.43 \\
37.93 \pm 1.56 \\
54.10 \pm 1.26 \\
92.71 \pm 0.43\end{array}$ & $12.28 \pm 0.19$ \\
\hline Kiwi & Fruit & $\begin{array}{l}1 \\
2 \\
3 \\
4\end{array}$ & $\begin{array}{l}19.46 \pm 1.47 \\
27.27 \pm 1.85 \\
34.49 \pm 0.55 \\
41.60 \pm 0.30\end{array}$ & $5.11 \pm 0.02$ \\
\hline Lemon & Fruit & $\begin{array}{c}0.0001 \\
0.001 \\
0.01 \\
0.5\end{array}$ & $\begin{array}{c}8.73 \pm 1.25 \\
18.20 \pm 1.47 \\
36.04 \pm 4.33 \\
47.60 \pm 0.34\end{array}$ & $0.049 \pm 0.001$ \\
\hline Pear & Fruit & $\begin{array}{c}5 \\
10 \\
15 \\
20\end{array}$ & $\begin{array}{l}12.65 \pm 2.16 \\
29.82 \pm 4.32 \\
56.68 \pm 1.16 \\
67.58 \pm 1.41\end{array}$ & $14.66 \pm 0.51$ \\
\hline Persimmon & Fruit & $\begin{array}{c}5 \\
10 \\
15 \\
20\end{array}$ & $\begin{array}{l}39.75 \pm 3.25 \\
56.28 \pm 4.07 \\
77.18 \pm 1.59 \\
89.54 \pm 0.61\end{array}$ & $7.89 \pm 0.93$ \\
\hline Pomegranate & Fruit & $\begin{array}{c}0.5 \\
1.5 \\
2 \\
5\end{array}$ & $\begin{array}{l}16.05 \pm 8.30 \\
24.47 \pm 3.20 \\
33.95 \pm 4.95 \\
53.64 \pm 4.35\end{array}$ & $4.43 \pm 0.55$ \\
\hline Quince & Fruit & $\begin{array}{c}2.5 \\
5 \\
7.5 \\
10\end{array}$ & $\begin{array}{l}17.28 \pm 0.71 \\
31.92 \pm 2.11 \\
50.33 \pm 0.79 \\
54.55 \pm 2.08\end{array}$ & $6.37 \pm 0.17$ \\
\hline Red apple & Fruit & $\begin{array}{c}5 \\
10 \\
15 \\
20\end{array}$ & $\begin{array}{l}18.98 \pm 0.38 \\
33.00 \pm 1.22 \\
50.33 \pm 0.79 \\
54.55 \pm 2.08\end{array}$ & $16.84 \pm 0.57$ \\
\hline Red radish & Root & $\begin{array}{c}5 \\
10 \\
15 \\
20\end{array}$ & $\begin{array}{c}5.80 \pm 1.76 \\
30.51 \pm 3.10 \\
70.97 \pm 3.68 \\
92.58 \pm 0.17\end{array}$ & $12.50 \pm 0.36$ \\
\hline White grape & Fruit & $\begin{array}{c}5 \\
7.5 \\
10 \\
15\end{array}$ & $\begin{array}{l}31.33 \pm 0.28 \\
53.36 \pm 2.69 \\
71.67 \pm 0.37 \\
90.77 \pm 0.25\end{array}$ & $7.35 \pm 0.17$ \\
\hline
\end{tabular}


Table 2. Adenosine deaminase inhibitory activities of some chemical compounds.

\begin{tabular}{|c|c|c|c|}
\hline Chemical compounds and standard & $\begin{array}{c}\text { Concentration } \\
(\mathrm{mg} / \mathrm{mL})\end{array}$ & Inhibition (\%)* & $1 \mathrm{C}_{50}(\mathrm{mg} / \mathrm{mL}) *$ \\
\hline Allopurinol & $\begin{array}{c}12.5 \\
25 \\
50 \\
100\end{array}$ & $\begin{array}{l}19.86 \pm 1.75 \\
44.25 \pm 7.19 \\
67.99 \pm 2.85 \\
79.68 \pm 1.88\end{array}$ & $42.14 \pm 2.25$ \\
\hline Adenine & $\begin{array}{c}25 \\
50 \\
75 \\
100\end{array}$ & $\begin{array}{l}40.05 \pm 0.74 \\
56.86 \pm 1.68 \\
64.33 \pm 1.44 \\
70.11 \pm 3.39\end{array}$ & $4.43 \pm 3.01$ \\
\hline $\mathrm{AgNO}_{3}$ & $\begin{array}{l}2 \\
3 \\
4 \\
5\end{array}$ & $\begin{array}{c}5.09 \pm 0.71 \\
21.73 \pm 1.41 \\
40.70 \pm 4.44 \\
57.86 \pm 0.90\end{array}$ & $4.55 \pm 0.12$ \\
\hline Biotin & $\begin{array}{c}1 \\
5 \\
7.5 \\
10\end{array}$ & $\begin{array}{c}9.85 \pm 1.22 \\
33.56 \pm 2.15 \\
53.60 \pm 0.95 \\
59.69 \pm 1.56\end{array}$ & $7.75 \pm 0.24$ \\
\hline $\mathrm{CuSO}_{4} \cdot 7 \mathrm{H}_{2} \mathrm{O}$ & $\begin{array}{l}1 \\
2 \\
3 \\
6\end{array}$ & $\begin{array}{l}11.71 \pm 0.69 \\
25.17 \pm 1.44 \\
36.63 \pm 1.77 \\
51.30 \pm 0.90\end{array}$ & $5.49 \pm 0.13$ \\
\hline Cytosine & $\begin{array}{c}1 \\
5 \\
10 \\
25\end{array}$ & $\begin{array}{l}22.25 \pm 1.30 \\
30.28 \pm 2.78 \\
44.33 \pm 1.06 \\
69.20 \pm 1.22\end{array}$ & $14.60 \pm 0.75$ \\
\hline Guanine & $\begin{array}{c}0.1 \\
1 \\
5 \\
10\end{array}$ & $\begin{array}{c}8.23 \pm 2.18 \\
33.01 \pm 0.89 \\
62.79 \pm 2.49 \\
88.05 \pm 0.56\end{array}$ & $4.29 \pm 0.28$ \\
\hline Guanosine & $\begin{array}{c}0.1 \\
1 \\
5 \\
10\end{array}$ & $\begin{array}{l}10.50 \pm 1.59 \\
18.61 \pm 1.97 \\
34.03 \pm 2.41 \\
44.34 \pm 3.24\end{array}$ & $11.08 \pm 0.99$ \\
\hline Kaempferol & $\begin{array}{c}0.001 \\
0.01 \\
0.05 \\
0.1\end{array}$ & $\begin{array}{l}13.70 \pm 1.83 \\
32.99 \pm 2.65 \\
52.87 \pm 0.81 \\
60.49 \pm 1.30\end{array}$ & $0.06 \pm 0.003$ \\
\hline Myrisitine & $\begin{array}{c}0.001 \\
0.01 \\
0.05 \\
0.1\end{array}$ & $\begin{array}{c}5.23 \pm 1.72 \\
20.31 \pm 1.17 \\
40.15 \pm 1.77 \\
55.63 \pm 0.77\end{array}$ & $0.081 \pm 0.002$ \\
\hline Nicotinamide & $\begin{array}{c}2.5 \\
5 \\
10 \\
100\end{array}$ & $\begin{array}{c}4.92 \pm 1.47 \\
20.88 \pm 1.47 \\
37.38 \pm 5.24 \\
51.38 \pm 1.30\end{array}$ & $92.45 \pm 4.43$ \\
\hline Quercetin & $\begin{array}{c}0.05 \\
0.1 \\
0.5 \\
1\end{array}$ & $\begin{array}{l}57.71 \pm 1.07 \\
65.84 \pm 0.94 \\
74.38 \pm 1.88 \\
85.90 \pm 0.47\end{array}$ & $0.004 \pm 0.0005$ \\
\hline Uracil & $\begin{array}{c}5 \\
10 \\
25 \\
50\end{array}$ & $\begin{array}{l}31.95 \pm 3.18 \\
48.07 \pm 0.53 \\
66.31 \pm 3.03 \\
76.71 \pm 0.77\end{array}$ & $16.17 \pm 2.17$ \\
\hline Xanthine & $\begin{array}{c}0.001 \\
0.01 \\
0.05 \\
0.1\end{array}$ & $\begin{array}{c}4.04 \pm 0.64 \\
9.64 \pm 0.45 \\
25.67 \pm 0.68 \\
34.82 \pm 2.33\end{array}$ & $0.14 \pm 0.005$ \\
\hline
\end{tabular}


Table 2. Continued.

\begin{tabular}{|c|c|c|c|}
\hline Vitamin U & $\begin{array}{c}5 \\
10 \\
25 \\
50\end{array}$ & $\begin{array}{l}29.80 \pm 1.88 \\
58.64 \pm 1.50 \\
77.04 \pm 0.80 \\
88.00 \pm 1.71\end{array}$ & $10.44 \pm 1.34$ \\
\hline $\mathrm{VOSO}_{4} \cdot \mathrm{H}_{2} \mathrm{O}$ & $\begin{array}{c}250 \\
500 \\
750 \\
1000\end{array}$ & $\begin{array}{l}26.88 \pm 4.79 \\
49.34 \pm 3.61 \\
58.67 \pm 0.84 \\
64.55 \pm 0.92\end{array}$ & $628.14 \pm 48.50$ \\
\hline $\mathrm{ZnSO}_{4} \cdot 7 \mathrm{H}_{2} \mathrm{O}$ & $\begin{array}{c}500 \\
1000 \\
2000 \\
3000\end{array}$ & $\begin{array}{l}12.39 \pm 1.15 \\
23.24 \pm 1.53 \\
27.78 \pm 0.47 \\
33.33 \pm 0.35\end{array}$ & $5074.60 \pm 70.00$ \\
\hline EHNA (Standard) & $\begin{array}{c}0.01 \\
0.1 \\
1 \\
10\end{array}$ & $\begin{array}{c}9.33 \pm 0.59 \\
32.31 \pm 0.89 \\
47.52 \pm 1.31 \\
69.20 \pm 1.22\end{array}$ & $6.38 \pm 1.13$ \\
\hline
\end{tabular}

radiotherapy and surgical operations (Arruebo et al., 2011). Nevertheless, hormone therapy as well as biological methods can be employed as a support to these main methods (Portenoy \& Ahmed, 2018). Despite advances in cancer treatment and use of these methods, challenges still exist. These challenges are due to individual variations, existence of variant forms of a cancer, requirements for modified treatment protocols, and nonexistence of an established single clear-cut standard procedure for treatment of all cancers types (Russo \& Sundaramurthi, 2019). For this reason, complementary and alternative treatment methods are necessary and significant besides main treatment methods. In this research, the effects of some plant extracts and chemical compounds on the activity of adenosine deaminase, which is found in virtually all the human tissues and plays a vital role in purine metabolism as well as development and maintenance of the immune system, were investigated.

Citruses are rich sources of vitamin C. In addition they are cheap sources of folic acid, potassium, pectin and a wide range of active phytochemical substances that can protect cells or tissues and improve wellbeing. Lemon has an important place among citrus fruits owing to its high content of vitamin C, its antioxidant activity and phenolic contents (Proteggente, Saija, De Pasquale, \& Rice-Evans, 2003; Gorinstein et al., 2004; Anagnostopoulou, Kefalas, Papageorgiou, Assimopoulou, \& Boskou, 2006; Guimarães et al., 2009). Citrus fruits are reported to exhibit a wide range of pharmacological properties including antiatherogenic, antiinflammatory, antitumor, antithrombotic as well as antioxidant activity (Alu'datt et al., 2017; Asencio et al., 2018; Musumeci et al., 2020). It is suggested that flavonoid compounds in citrus fruits (such as quercetin, myricetin and kaempferol and their derivatives) are responsible for an inhibitory effect on ADA activity, as well as in vivo modulation of hepatic lipid metabolism (Cha et al., 2001). A study by Arun et al., reported that hibifolin molecule (a flavonoid type substance) inhibited ADA activity (Arun et al., 2016). The high ADA inhibitory potential of lemon $\left(I C_{50}\right.$ value of $0.050 \pm 0.001 \mathrm{mg} / \mathrm{mL}$ ) observed in this study may be attributed to the aforementioned flavonoids present in lemon fruit extract. On the other hand, quercetin followed by kaempferol $\left(I C_{50}=0.004 \pm 0.0005 \mathrm{mg} / \mathrm{mL}\right.$ and $0.06 \pm 0.003 \mathrm{mg} / \mathrm{mL}$ respectively) which have been previously reported to be present in citrus extract had the highest inhibitory effect on ADA activity when compared to other chemical substances used in this study. Therefore, a strong correlation exists between these flavonoids and the high ADA inhibitory action of lemon extract.

\section{CONCLUSION}

It can be concluded that the consumption of quercetin and kaempferol rich fruits/foods such as lemons may serve as a potential source of ADA inhibitor and ultimately affect purine metabolism as well as the maintenance of the immune system in cancer patients.

Peer-review: Externally peer-reviewed.

Author Contributions: Conception/Design of Study- Ö.S.; Data Acquisition- Ö.S., A.T.; Data Analysis/Interpretation- Ö.S., A.T.; Drafting Manuscript- Ö.S., A.T.; Critical Revision of Manuscript-Ö.S.; Final Approval and Accountability- Ö.S., A.T.

Conflict of Interest: The authors have no conflict of interest to declare.

Financial Disclosure: Authors declared no financial support.

\section{REFERENCES}

- $\quad$ Aiuti, A., Cattaneo, F., Galimberti, S., Benninghoff, U., Cassani, B., Callegaro, L., ... Roncarolo, M. G. (2009). Gene therapy for immunodeficiency due to adenosine deaminase deficiency. New England Journal of Medicine, 360, 447-458. https://www.nejm.org/ doi/full/10.1056/NEJMoa0805817

- $\quad$ Aldrich, M. B., Blackburn, M. R., \& Kellems, R. E. (2000). The importance of adenosine deaminase for lymphocyte development and function. Biochemical and Biophysical Research Communications, 72, 311-315. https://doi.org/10.1006/bbrc.2000.2773 
- $\quad$ Alu'datt, M. H., Rababah, T., Alhamad, M. N., Al-Mahasneh, M. A., Ereifej, K., Al-Karaki, G., ... Ghozlana, K. A. (2017). Profiles of free and bound phenolics extracted from Citrus fruits and their roles in biological systems: content, and antioxidant, anti-diabetic and anti-hypertensive properties. Food and Function, 8, 3187-3197. https://doi.org/10.1039/C7FO00212B

- Anagnostopoulou, M. A., Kefalas, P., Papageorgiou, V. P., Assimopoulou, A. N., \& Boskou, D. (2006). Radical scavenging activity of various extracts and fractions of sweet orange flavedo (Citrus sinensis). Food Chemistry, 94, 19-25. https://doi.org/10.1016/j.foodchem.2004.09.047

- $\quad$ Arruebo, M., Vilaboa, N., Sáez-Gutierrez, B., Lambea, J., Tres, A., Valladares, M., \& González-Fernández, A. (2011). Assessment of the evolution of cancer treatment therapies. Cancers, 3, 3279-3330. http://dx.doi:10.3390/cancers3033279

- Arun, K. G., Sharanyaa, C. S., Sandeepa, P. M., \& Sadasivana, C. (2016). Inhibitory activity of hibifolin on adenosine deaminaseexperimental and molecular modeling study. Computational Biology and Chemistry, 64, 353-358. https://doi.org/10.1016/j.compbiolchem.2016.08.005

- Asencio, A. D., Serrano, M., Garcia-Martinez, S., \& Pretel, M. T. (2018). Organic acids, sugars, antioxidant activity, sensorial and other fruit characteristics of nine traditional Spanish citrus fruits. European Food Research and Technology, 244, 1497-1508. https:// doi.org/10.1007/s00217-018-3064-x

- Blum, U., \& Schwedt, G. (1998). Inhibition behavior of phosphatase, phosphodiesterase I and adenosine deaminase as tools for trace metal analysis and speciation. Analytica Chimica Acta, 360, 101-108. https://doi.org/10.1016/S0003-2670(97)00717-4

- Canbolat, O., Akyol, O., Kavutcu, M., Isik, A. Ü., \& Durak, I. (1994). Serum adenosine deaminase and total superoxide dismutase activities before and after surgical removal of cancerous laryngeal tissue. Journal of Laryngology and Otology, 108, 849-851. https:// doi.org/10.1017/S0022215100128300

- Colditz, G. A., \& Wei, E. K. (2012). Preventability of cancer: The relative contributions of biologic and social and physical environmental determinants of cancer mortality. Annual Review and Public Healthy, 33, 137-156. https://www.annualreviews.org/doi/ abs/10.1146/annurev-publhealth-031811-124627

- Cha, J. Y., Cho, Y. S., Kim, I., Anno, T., Rahman, S. M., \& Yanagita, T. (2001). Effect of hesperitin, a citrus flavonoid, on the liver triacylglycerol content and phosphatidate phosphohydrolase activity in orotic acid-fed rats. Plant Foods for Human Nutrition, 56, 349-358. Retrieved from https://www.ncbi.nlm.nih.gov/ pubmed/11678440

- Dolezelova, E., Zurovec, M., Dolezal, T., Simek, P., \& Bryant, P. J. (2005). The emerging role of adenosine deaminases in insects. Insect Biochemistry and Molecular Biology, 35, 381-389. https://doi. org/10.1016/j.ibmb.2004.12.009

- $\quad$ Fleischman, A., Hershfield, M. S., Toutain, S., Lederman, H. M., Sullivan, K. E., Fasano, M. B., ...Winkelstein, J. A. (1998). Adenosine deaminase deficiency and purine nucleoside phosphorylase deficiency in common variable immunodeficiency. Clinical and Diagnostic Laboratory Immunology, 5, 399-400. Retrieved from https://www.ncbi.nlm.nih.gov/pmc/articles/PMC104530

- Gorinstein, S., Cvikrova, M., Machackova, l., Haruenkit, R., Park, Y. S., Jung, S. T., ... Trakhtenberg, S. (2004). Characterization of antioxidant compounds in Jaffa sweeties and white grapefruits. Food Chemistry, 84, 503-510. https://doi.org/10.1016/S0308-8146(03)00127-4

- Guimarães, R., Barros, L., Barreira, J. C. M., Sousa, M. J., Carvalho, A. M., \& Ferreira, I. C. F. R. (2009). Targeting excessive free radicals with peels and juices of citrus fruits: grapefruit, lemon, lime and orange. Food and Chemical Toxicology, 48, 99-106. https://doi. org/10.1016/j.fct.2009.09.022
Hoffbrand, A. V., \& Janossy, G. (1981). Enzyme and membrane markers in leukaemia: recent developments. Journal of Clinical Pathology, 34, 254-262. Retrieved from https://jcp.bmj.com/content/34/3/254

İbiş, M., Koklu, S., Yilmaz, F. M., Basar, O., Yilmaz, G., Yuksel, O., ... Ozturk, Z. A. (2007). Serum adenosine deaminase levels in pancreatic diseases. Pancreatology, 7, 526-530. https://doi. org/10.1159/000108970

Lal, H., Munjal, S. K., Wig, U., \& Saini, A. S. (1987). Serum enzymes in head and neck cancer III. Journal of Laryngology and Otology, 101, 1062-1065. https://doi.org/10.1017/S0022215100103226

Markman, J. L., \& Shiao, S. L. (2015). Impact of the immune system and immunotherapy in colorectal cancer. Journal of Gastrointestinal Oncology, 6(2), 208-223. https://doi.org/10.3978/j.issn.20786891.2014.077

Musumeci, L., Maugeri, A., Cirmi, S., Lombardo, G. E., Russo, C., Gangemi, S., ... Navarra, M. (2020) Citrus fruits and their flavonoids in inflammatory bowel disease: an overview. Natural Product Research, 34, 122-136. https://doi.org/10.1080/14786419.2019.1601 196

Nishihara, H., Akedo, H., Okada, H., \& Hattori, S. (1970). Multienzyme patterns of serum adenosine deaminase by agar gel electrophoresis: an evaluation of the diagnostic value in lung cancer. Clinica Chimica Acta, 30, 251-258. https://doi.org/10.1016/00098981(70)90110-5

Ozdemir, A., Kaplan Serin, E., \& Savas, M. (2018). Cancer risk factors and prevention in Turkey. International Journalof Health Services Research and Policy, 3, 143-150. https://doi.org/10.23884/ ijhsrp.2018.3.3.06

Portenoy, R. K., \& Ahmed, E. (2018). Cancer pain syndromes. Hematology / Oncology Clinics, 32, 371-386. https://doi.org/10.1016/j. hoc.2018.01.002

Proteggente, A. R., Saija, A., De Pasquale, A., \& Rice-Evans, C. A. (2003). The compositional characterisation and antioxidant activity of fresh juices from Sicilian sweet orange (Citrus sinensis L. Osbeck) varieties. Free Radicical Research, 37, 681-687. https://doi. org/10.1080/1071576031000083198

Russo, M. M., \& Sundaramurthi, T. (2019). An overview of cancer pain: Epidemiology and pathophysiology. Seminars in Oncology Nursing, 35, 223-228. https://doi.org/10.1016/j.soncn.2019.04.002 Soerjomataram, I., Kevin Shield, K., Marant-Micallef, C., Vignat, J., Hill, C., Rogel, A., ... Bray, F. (2018). Cancers related to lifestyle and environmental factors in France in 2015. European Journal of Cancer, 105,103-113. https://doi.org/10.1016/j.ejca.2018.09.009

Van der Weyden, M. B., \& Kelley, W. N. (1976). Human adenosine deaminase. Journal of Biological Chemistry, 251(18), 5448-5456. Retrieved from https://www.jbc.org/content/251/18/5448

Walia, M., Mahajan, M., \& Singh, K. (1995). Serum adenosine deaminase, 5'-nucleotidase \& alkaline phosphatase in breast cancer patients. The Indian Journal of Medical Research, 101, 247-249. Retrieved from https://europepmc.org/article/med/7672835

- Willett W. C. (2000). Diet and cancer. The Oncologist; 5, 393-404. https://doi.org/10.1634/theoncologist.5-5-393

Wang, M., Chen, J., Su, D., Wang, G., \& Su, X. (2019). Split aptamer based sensing platform for adenosine deaminase detection by fluorescence resonance energy transfer. Talanta, 198, 1-7. https:// doi.org/10.1016/j.talanta.2019.01.041

Zaigham, A., \& Sakina, R. (2018). An overview of cancer treatment modalities. In HN Shahzad (Ed.), Neoplasm (pp 139-157), London, UK: Intechopen Ebook Press. 